\title{
Vitamin D-regulated osteocytic sclerostin and BMP2 modulate uremic extraskeletal calcification
}

\author{
Loan Nguyen-Yamamoto, ${ }^{1}$ Ken-Ichiro Tanaka, ${ }^{1}$ Rene St-Arnaud, ${ }^{2,3}$ and David Goltzman ${ }^{1}$ \\ 'Department of Medicine, McGill University and McGill University Health Centre, Montreal, Quebec, Canada. ${ }^{2}$ Departments \\ of Surgery and Human Cenetics, McGill University, Montreal, Quebec, Canada. ${ }^{3}$ Research Centre, Shriners Hospital for \\ Children, Montreal, Quebec, Canada.
}

\begin{abstract}
We induced chronic kidney disease (CKD) with adenine in WT mice, mice with osteocyte-specific deletion of Cyp27b1, encoding the 25-hydroxyvitamin D 1(OH)ase [Oct-1(OH)ase $\left.{ }^{-1}\right]$, and mice with global deletion of $C y p 27 b 1$ [global-1 $1 \alpha(\mathrm{OH})$ ase ${ }^{-/}$]; we then compared extraskeletal calcification. After adenine treatment, mice displayed increased blood urea nitrogen, decreased serum $1,25(\mathrm{OH})_{2} \mathrm{D}$, and severe hyperparathyroidism. Skeletal expression of Cyp27b1 and of sclerostin and serum sclerostin

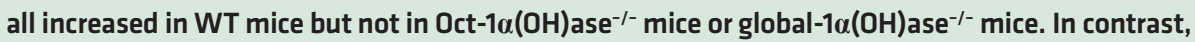
skeletal expression of BMP2 and serum BMP2 rose in the $\mathrm{Oct}-1 \alpha(\mathrm{OH})$ ase $\mathrm{e}^{-1-}$ mice and in the global$1 \alpha(\mathrm{OH})$ ase $^{-1-}$ mice. Extraskeletal calcification occurred in muscle and blood vessels of mice with CKD and was highest in $\mathrm{Oct}-1 \alpha(\mathrm{OH})$ ase ${ }^{-1-}$ mice. In vitro, recombinant sclerostin $(100 \mathrm{ng} / \mathrm{mL})$ significantly suppressed BMP2-induced osteoblastic transdifferentiation of vascular smooth muscle A7r 5 cells and diminished BMP2-induced mineralization. Our study provides evidence that local osteocytic production of $1,25(\mathrm{OH})_{2} \mathrm{D}$ stimulates sclerostin and inhibits BMP2 production in murine CKD, thus mitigating osteoblastic transdifferentiation and mineralization of soft tissues. Increased osteocytic $1,25(\mathrm{OH})_{2} \mathrm{D}$ production, triggered by renal malfunction, may represent a "primary defensive response" to protect the organism from ectopic calcification by increasing sclerostin and suppressing BMP2 production.
\end{abstract}

Conflict of interest: The authors have declared that no conflict of interest exists.

Copyright: (c) 2019 American Society for Clinical Investigation

Submitted: November 27, 2018

Accepted: May 28, 2019

Published: July 11, 2019.

Reference information: /CI Insight. 2019;4(13):e126467. https://doi. org/10.1172/jici.insight.126467

\section{Introduction}

Mineral and bone disorder (MBD) develops during the course of chronic kidney disease (CKD), perturbing mineral homeostasis and inducing biochemical abnormalities that cause bone disease and soft-tissue calcification, including vascular calcification. Vascular calcification appears to increase in severity as CKD progresses (1). In both humans $(2,3)$ and mice (4), one of the earliest metabolic modifications of mineral metabolism observed in CKD appears to be an increase in serum levels of FGF23, the bone hormone involved in promoting phosphaturia, inhibiting synthesis of the active form of vitamin $\mathrm{D}, 1,25$-dihydroxyvitamin $\mathrm{D}\left[1,25\left(\mathrm{OH}_{2} \mathrm{D}\right)\right]$ and reducing levels of parathyroid hormone; concomitantly, circulating soluble Klotho, a protein synthesized by renal tubular cells and a coreceptor of FGF23, appears to decrease (5). These alterations in FGF23 and Klotho are regarded as some of the earliest disturbances of bone-kidney cross-talk, which represent one of the pathophysiologic components of CKD-MBD. The osteocyte, previously thought to be a relatively quiescent cell with a role limited to skeletal mechanosensing, can act as an osseous endocrine cell (6) synthesizing FGF23, but also sclerostin, a potent inhibitor of the Wnt growth factor signaling pathway and BMP2 (7-9). The highest osteocyte expression of Sost, the gene encoding sclerostin, also occurs at initial stages of CKD (10), and inhibition of the osteocyte Wnt pathway was demonstrated to be an early event in the progression of CKD-MBD, using an animal model of CKD (10), although sclerostin may also be produced by calcified soft tissues (11) and increase as kidney function declines further (12).

BMP2 is a member of the TGF- $\beta$ superfamily (9), members of which were originally discovered as inducers of ectopic bone (13), and also detected in cartilage and bone (14). BMPs, by activating the Wnt pathway, promote bone formation (15-17). Consequently, any factors that regulate their production and activities might be expected to have an influence on the mineralization process in extraskele- 
tal as well as in skeletal compartments. Therefore, any disruption of the normal biology of the osteocyte could trigger alterations in skeletal and extraskeletal mineralization.

Circulating concentrations of calcification inhibitors, such as fetuin-A and osteoprotegerin (OPG), and promoters, such as phosphorus, may contribute to modulating the extraskeletal calcification that occurs in CKD (18). However, site-specific transdifferentiation of muscle cells to osteogenic cells has also been described as contributing to extravascular calcification. This process appears to be enhanced by the action of a variety of secreted molecules, including IGF-1, FGF2, osteoglycin, family with sequence similarity 5 (FAM5), IL-7, IL-5, irisin, follistatin, osteonectin, and MMP-2 (19). Advanced glycation end products (AGE) have also been demonstrated to induce transdifferentiation of vascular smooth muscle cells (VSMC) to bone cells, as has strontium ranelate (20). Oxidant stress (21) and endoplasmic reticulum stress (22) may initiate VSMC transdifferentiation by upregulating expression of runt domain-containing transcription factor 2 (Runx2), a principal regulator in the process of differentiation of osteoblasts from their mesenchymal precursors (23) and a key factor organizing gene transcription during the development and maturation of osteoblasts (24).

The Wnt signaling pathway plays a critical role in osteogenic differentiation (25). In the canonical pathway, binding of Wnt proteins to a membrane receptor, frizzled (Fzd), and a coreceptor, lipoprotein-related protein (LRP) 5 or 6, results in phosphorylation of the intracellular cytoplasmic tail of LRP5 or LRP6, with subsequent disruption of an intracellular "protein destruction" complex that includes dishevelled (Dsh), axin, adenomatous polyposis coli (APC), and glycogen synthase kinase-3 $\beta$ (GSK-3 $\beta$ ) and that otherwise facilitates the phosphorylation of $\beta$-catenin, thus targeting $\beta$-catenin for ubiquitin-dependent proteolytic degradation. With reduced phosphorylation, stabilization and translocation of $\beta$-catenin to the nucleus occurs, and nuclear $\beta$-catenin then interacts with transcription factors of the Tcf/Lef family to activate specific gene expression programs enhancing osteoblastogenesis and inhibiting osteoclastogenesis (26). Exosomes from myoblasts may promote osteoblastic differentiation by increasing miR-27a-3p levels in recipient preosteoblasts, decreasing expression of APC, and activating the $\beta$-catenin pathway (27). Inflammatory cytokines may also activate the Wnt pathway in mineralizing blood vessels, increasing expression of Runx2 (28) and other bone-related genes, such as Rankl, osteocalcin (Bglap), and alkaline phosphatase (Alpl) (29). The Wnt signaling pathway can also be downregulated by several molecules, including sclerostin, which can bind to the Wnt coreceptor LRP5 (or LRP6) (30-32). In addition, a study of calcifying human primary aortic smooth muscle cells (33) showed that sclerostin was able to downregulate Runx 2 expression and restored $\alpha$-smooth muscle actin activity. Direct inhibition of the osteoblastic Wnt pathway by FGF23 may also occur (34). Several studies have also reported the association of FGF23 and sclerostin with cardiovascular calcification and mortality, and anti-FGF23 and anti-Sost have been examined in the treatment of CKD; however, most of these studies were conducted at an advanced or late stage of $\mathrm{CKD}$, and no consensus was reached.

It has been reported that vitamin $\mathrm{D}$ deficiency is a risk factor for aortic calcification and a stimulator of osteogenic gene expression (35), and low circulating levels of 25-hydroxyvitamin $\mathrm{D}$ [25(OH)D] have been associated with an increased risk of cardiovascular disease in humans (36-40). In $\mathrm{Ldl}^{-1-}$ high fat-fed mice with $\mathrm{CKD}$, administration of doses of calcitriol and paracalcitol that normalized secondary hyperparathyroidism were effective in protecting against aortic calcification; however, higher dosages produced the opposite effect (41). It has also been reported that locally produced $1,25(\mathrm{OH})_{2} \mathrm{D}$ in vascular cells may promote arterial calcification in uremic rats and mice (42). Importantly, $1,25(\mathrm{OH})_{2} \mathrm{D}$, acting in bone cells, is also known to directly upregulate gene expression of Fgf23 (4) and Sost (43-45) via binding of the vitamin D receptor (VDR) to vitamin D response elements (VDREs); we previously reported in a mouse model of CKD (4) that increased local $1,25(\mathrm{OH})_{2} \mathrm{D}$ production in mature osteoblasts/osteocytes increased FGF23 production. $1,25(\mathrm{OH})_{2} \mathrm{D}$ can also transcriptionally repress $B m p 2$ gene expression through the VDR via an epigenetic mechanism (46).

Using our mouse model of adenine-induced CKD (4), we report here that bone $1 \alpha$-hydroxylase may play a central role in the regulation of sclerostin, BMP2, and FGF23 in CKD and that these osteocyte products contribute to the development and progression of extraskeletal calcification in CKD-MBD.

\section{Results}

Serum biochemistry. A mouse model of CKD was induced by feeding an adenine diet for 5 weeks to 8-weekold male WT mice and mice in which the Cyp27b1 gene, which encodes the 25-hydroxyvitamin D-1 $\alpha$ hydroxylase $(1 \alpha(\mathrm{OH})$ ase $)$, was deleted specifically from osteocytes (Oct) or was globally deleted. Kidney function was monitored by measuring blood urea nitrogen (BUN). Additional biochemistry parameters were also monitored and results were compared with mice of the same genotype on an adenine-free diet. 


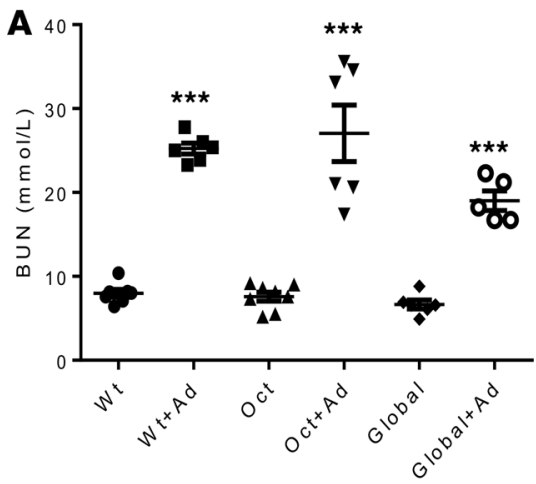

D

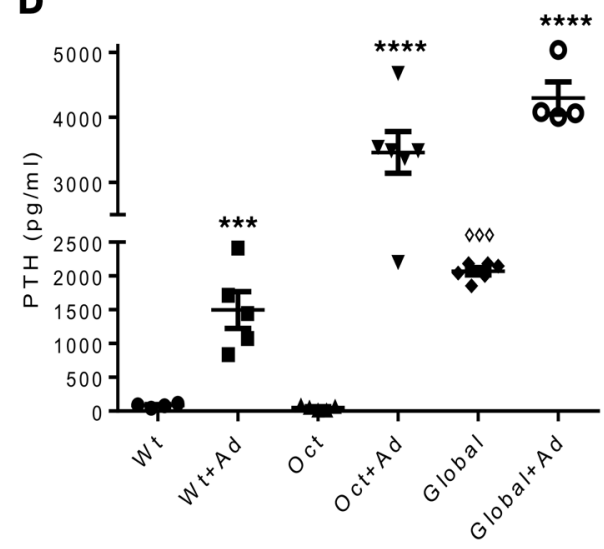

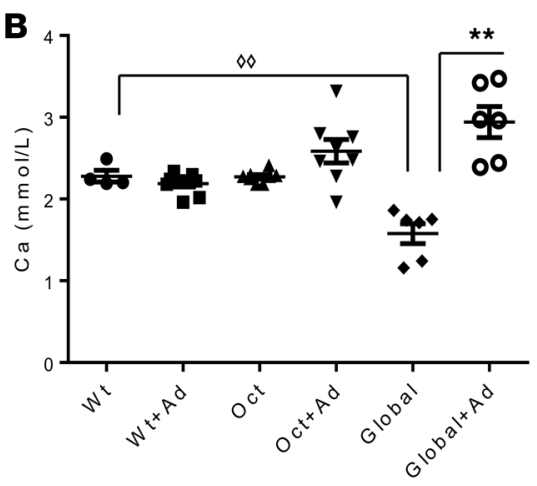
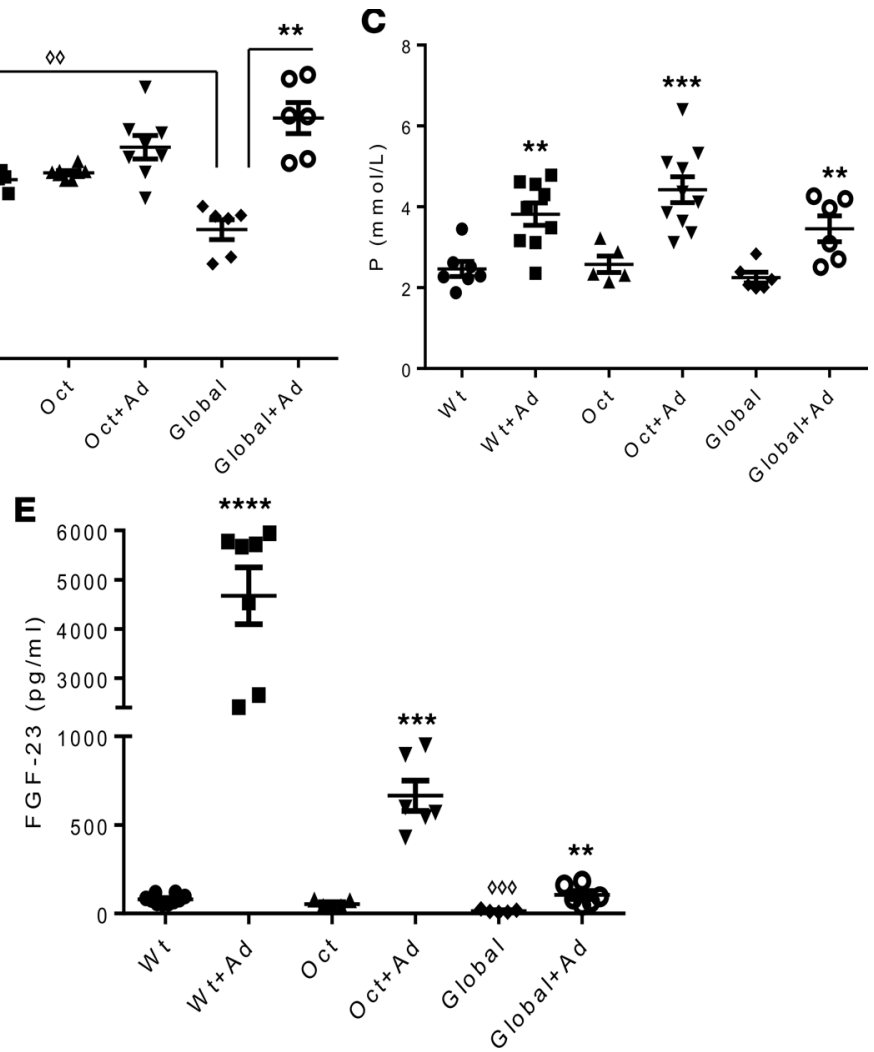

Figure 1. Serum biochemistry. Serum levels of (A) blood urea nitrogen (BUN), (B) calcium (Ca), (C) phosphate (P), (D) parathyroid hormone (PTH), and (E) FGF23 in WT mice, osteocyte-specific $1 \alpha \mathrm{OHase}^{-/-} \mathrm{KO}$ mice (Oct), and global $1 \alpha \mathrm{OHase}{ }^{-/-} \mathrm{KO}$ mice (Clobal) at 13 weeks of age. "Ad" indicates treatment with adenine. Global $1 \alpha \mathrm{OHase}^{-/-} \mathrm{KO}$ mice remained on a high calcium diet during the course of the experiments. Data are the mean $\pm \mathrm{SEM}(n=6-8 \mathrm{mice}$ of each genotype). ${ }^{* * *} P \leq 0.0001$, ${ }^{* * *} P \leq 0.001$, ${ }^{* *} P \leq 0.01$, ${ }^{*} P \leq 0.05$ compared with mice of the same genotype on a non-adenine-containing diet, and ${ }^{\circ \diamond 0} P \leq 0.001$, ${ }^{\diamond} P \leq 0.01$ compared with WT mice, determined by ANOVA with Bonferroni multiple comparison test.

After 5 weeks on the adenine diet, reduced kidney function was confirmed in all models by a significant increase in BUN levels (Figure 1A). Calcium levels were increased in global- $1 \alpha(\mathrm{OH})$ ase $^{-/-}$mice that had received adenine with a high calcium intake but were unchanged in Oct- $1 \alpha(\mathrm{OH})$ ase $^{-/-}$and WT mice on the adenine diet with normal calcium intake (Figure 1B). Phosphate levels were increased in all groups of adenine-treated mice (Figure 1C). Serum parathyroid hormone (PTH) showed a significant increase in all groups of adenine-treated mice compared with mice of the same genotype maintained on a non-adenine-containing diet (Figure 1D). Serum FGF23 of adenine-treated WT mice rose to over 4,000 pg/mL; however, in Oct- $1 \alpha(\mathrm{OH})$ ase $\mathrm{e}^{-/}$and in global-1 $\alpha(\mathrm{OH}) \mathrm{ase}^{-/-}$mice only a relatively small increase was observed with the adenine diet (Figure 1E).

Expression of Cyp27b1 and Cyp24a in bone and serum levels of 25(OH)D and 1,25(OH $)_{2} D$. We measured the expression of Cyp27b1 mRNA by real-time PCR in bone of both WT mice and mice with osteocyte-specific deletion of Cyp27b1, maintained on a regular or an adenine diet for 2 days. Cyp27b1 expression in bone of WT and Oct-1 $\alpha(\mathrm{OH}) \mathrm{ase}^{-/-}$mice was low to undetectable when mice were kept on a regular diet; 2 days after beginning an adenine diet, skeletal Cyp27b1 expression increased significantly in WT mice, whereas no change occurred in Oct- $1 \alpha(\mathrm{OH})^{-/-}$mice. The expression of skeletal Cyp24a1, which encodes the metabolizing enzyme $24(\mathrm{OH})$ ase, was low to undetectable on a regular diet and was not changed by the adenine diet in all groups of mice (Figure $2 \mathrm{~A}$ ). The serum levels of $25(\mathrm{OH}) \mathrm{D}$ were not significantly different from each other in WT, Oct- $1 \alpha(\mathrm{OH})$ ase $^{-/-}$, and global- $1 \alpha(\mathrm{OH}) \mathrm{ase}^{-/-}$mice both before and after treatment with adenine (Figure $2 \mathrm{~B}$ ). Serum levels of $1,25(\mathrm{OH})_{2} \mathrm{D}$ were not significantly different in WT mice and in Oct- $1 \alpha(\mathrm{OH})$ ase $^{-/-}$mice either before or after treatment with adenine, but serum $1,25(\mathrm{OH})_{2} \mathrm{D}$ fell in both WT and Oct- $1 \alpha(\mathrm{OH})$ ase $^{-/-}$mice after treatment with adenine compared with mice of the same genotype on a regular diet (Figure $2 \mathrm{C}$ ). Serum $1,25(\mathrm{OH})_{2} \mathrm{D}$ was undetectable in all global- $1 \alpha(\mathrm{OH})$ ase $^{-/-}$mice. Thus, an increase of $C y p 27 b 1$ expression in bone was an early response to adenine-induced $\mathrm{CKD}$ in our mouse model but did not contribute to circulating $1,25(\mathrm{OH})_{2} \mathrm{D}$ levels. 

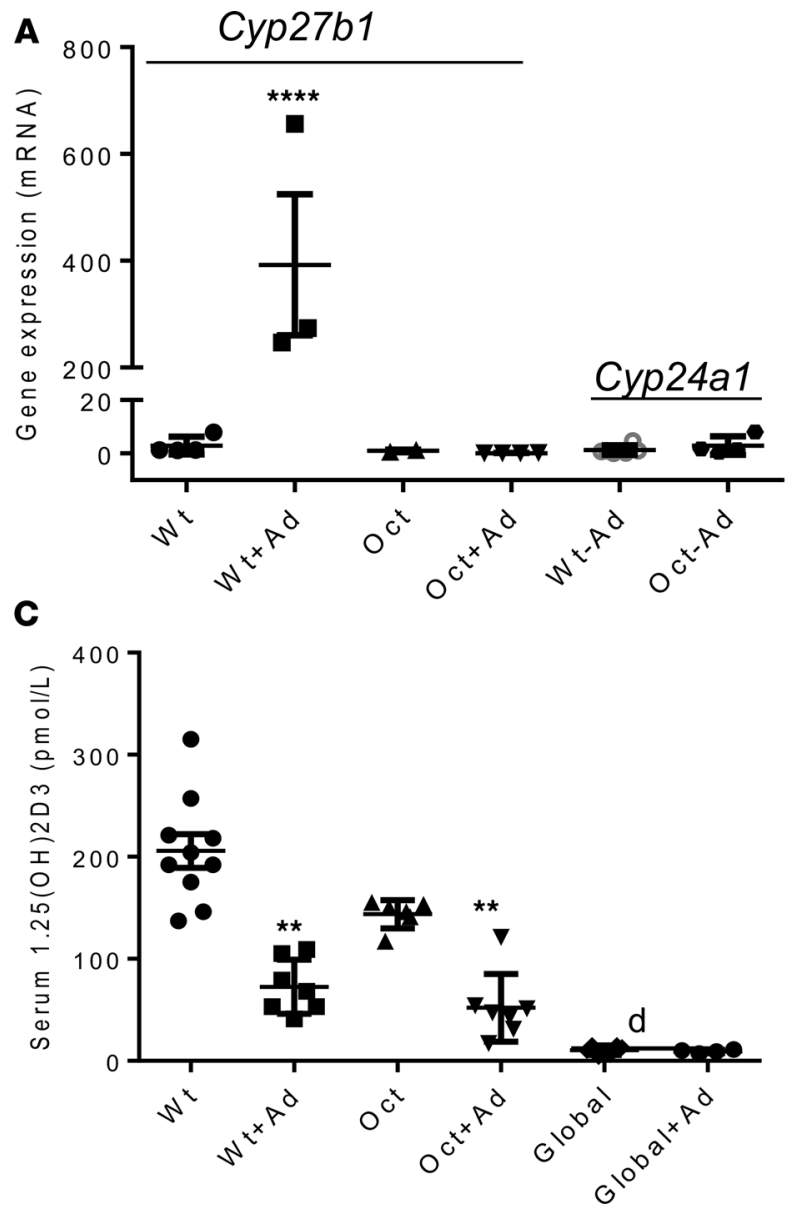

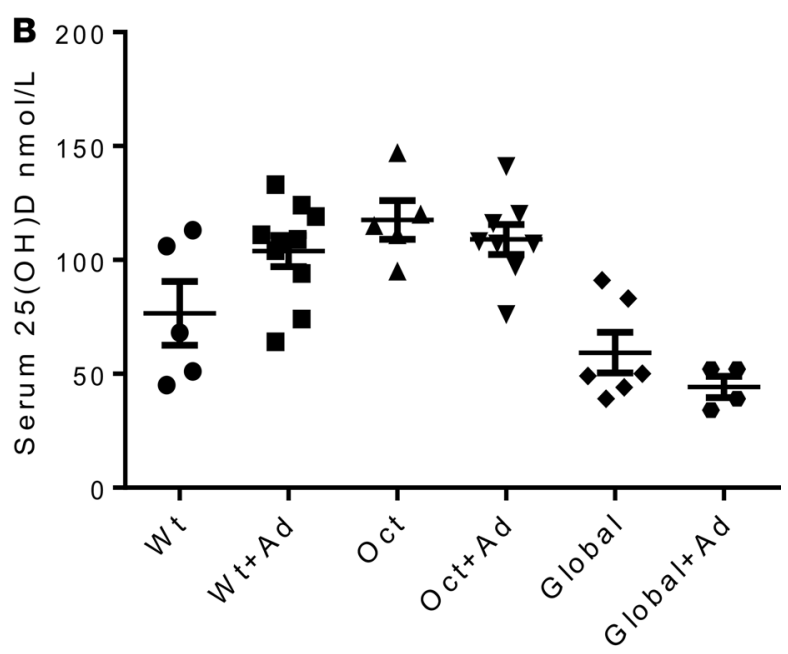

Figure 2. mRNA levels of bone Cyp27b1 (encoding 1a(OH)ase activity) and Cyp24a1(encoding 24(OH)ase activity) and serum levels of 25(OH)D and $\mathbf{1 , 2 5 ( O H )}$ D. Total RNA was extracted from bone marrow-flushed femurs and mRNA levels of bone Cyp27b1 and Cyp24a1 were determined by RT-PCR and normalized to Gapdh mRNA (A). Data are the mean \pm SEM of at least 3 independent experiments, $n=3-6 /$ experiment. ${ }^{* * *} P<0.0001$ in adenine-treated WT mice compared with WT mice on a regular diet, determined by Student's $t$ test. Serum levels of 25(OH)D and $(\mathbf{C})$ serum levels of $1,25(\mathrm{OH})_{2} \mathrm{D}$, as determined by ELISA, in WT mice, osteocyte-specific $1 \alpha \mathrm{OHase}^{-/-} \mathrm{KO}$ mice (Oct), and global $1 \alpha \mathrm{OHase}^{-/-} \mathrm{KO}$ mice (Global). (B). "Ad" indicates treatment with adenine. Global $1 \alpha \mathrm{OHase}^{-1-} \mathrm{KO}$ mice remained on a high calcium diet during the course of the experiments. "d" represents the detection limit of the assay for $1,25(\mathrm{OH})_{2} \mathrm{D}$. Data are the mean \pm SEM ( $n=6-8$ mice of each genotype). ${ }^{*} P \leq 0.01$ compared with mice of the same genotype on a non-adeninecontaining diet, determined by ANOVA with Bonferroni multiple comparison test.

Upregulation of sclerostin. The effect of osteocytic production of $1,25(\mathrm{OH})_{2} \mathrm{D}$ on sclerostin was studied after 1 week on an adenine diet by IHC analysis of femurs and compared with mice of the same genotype on a regular diet (Figure 3A). Quantification of IHC staining was determined as the number of positively stained cells per $300 / \mathrm{mm}^{2}$ of bone tissue (Figure 3B). Sclerostin was detected in femurs of WT and Oct- $1 \alpha(\mathrm{OH}) \mathrm{ase}^{-1-}$ mice on a regular diet and of global $-1 \alpha(\mathrm{OH}) a_{s e^{-/}}$mice on a high calcium diet, but there was less positive staining in Oct- $1 \alpha(\mathrm{OH}) a s e^{-/-}$and global- $1 \alpha(\mathrm{OH}) a s e^{-/-}$mice bone compared with WT mice (Figure 3, A and B). However, 1 week after treatment with adenine, sclerostin expression in WT mice was increased, although no increase was observed in Oct- $1 \alpha(\mathrm{OH}) \mathrm{ase}^{-/-}$and global- $\alpha 1(\mathrm{OH}) \mathrm{ase}^{-/-}$mice (Figure 3, A and B). Serum sclerostin levels in WT mice rose after 1 week on an adenine diet and continued to increase as CKD progressed; however, no significant increase was observed in Oct- $1 \alpha(\mathrm{OH}) \mathrm{ase}^{-/-}$and global- $1 \alpha(\mathrm{OH})$ ase $^{-/-}$mice (Figure $3 \mathrm{C}$ ).

Therefore, because sclerostin expression in bone and circulating sclerostin levels was increased when Cyp27b1 levels in osteocytes were increased (i.e., after adenine treatment of WT mice) and sclerostin was not

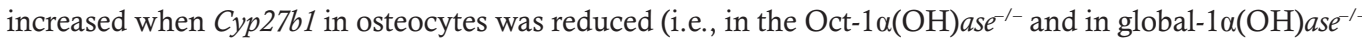
mice), our results indicate that bone sclerostin expression and secretion into the circulation in this CKD mouse model was dependent on $1 \alpha(\mathrm{OH})$ ase activity in osteocytes.

Downregulation of BMP2. Because downregulation of $B m p 2$ expression by $1,25(\mathrm{OH})_{2} \mathrm{D}$ has been previously reported ex vivo and in vitro (46), we examined skeletal expression and serum levels of BMP2 in our models. To examine Bmp2 expression, total RNA was extracted from bone and subjected to real-time PCR analysis (Figure 4A). In the absence of adenine administration, bone expression of BMP2 was detected in WT mice but was significantly higher in Oct- $1 \alpha(\mathrm{OH}) \mathrm{ase}^{-/-}$and global- $1 \alpha(\mathrm{OH})$ ase $^{-/-}$mice (Figure $4 \mathrm{~A}$ ). The results in global- $1 \alpha(\mathrm{OH}) a s e^{-/-}$mice, with their inability to synthesize $1,25(\mathrm{OH})_{2} \mathrm{D}$, indicated the negative regulatory role of $1,25(\mathrm{OH})_{2} \mathrm{D}$ on $\mathrm{Bmp} 2$ expression; the results in Oct- $1 \alpha(\mathrm{OH}) a e^{-/-}$mice, which are unable to synthesize $1,25(\mathrm{OH})_{2} \mathrm{D}$ in osseous cells, indicated that locally produced $1,25(\mathrm{OH})_{2} \mathrm{D}$ contributes to this negative regulation. After 1 week of treatment with an adenine diet in the WT mice, in which osseous Cyp $27 b 1$ was elevated (Figure 2), bone Bmp2 expression was reduced; however, a significant increase 
A


† Sclerostin Positive $(\times 400)$
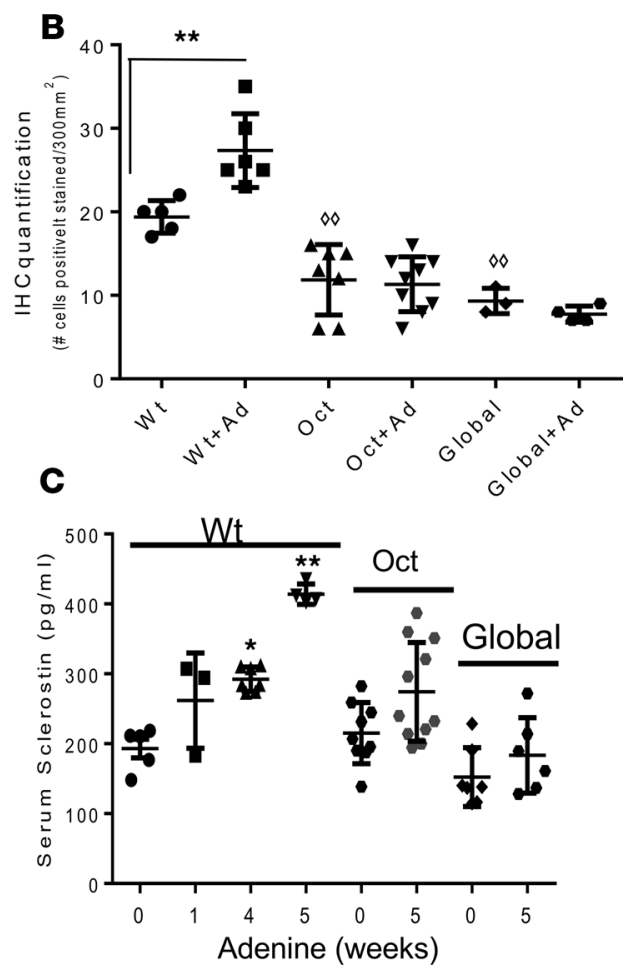

Figure 3. Bone sclerostin expression by IHC and serum sclerostin levels. Positive immunohistochemical staining for sclerostin in osteocytes is shown in brown and staining in canaliculi and/or lacunae are shown by the red arrows (A). Counterstaining was with Mayers Hematoxylin. Original magnification, $\times 400$. IHC staining was quantified as the number of positively stained cells per surface area of bone tissue, using Image) software, and $300 \mathrm{~mm}^{2}(650 \times$ $500 \mu \mathrm{m}$ ) of surface area was analyzed (B). Data are presented as the mean \pm SEM of the number of positively stained cells per area of bone tissue (300 $\mathrm{mm}^{2}$ ) in mice of the indicated genotype. ${ }^{* *} P \leq 0.01$ compared with mice of the same genotype maintained on a non-adenine-containing diet determined by Student's $t$ test, ${ }^{\diamond} \mathrm{P} \leq 0.01$ compared to WT mice on a non-adenine diet determined by ANOVA with Bonferroni adjustment. Serum levels of sclerostin in WT mice, osteocyte-specific $1 \alpha \mathrm{OHase}^{-1-} \mathrm{KO}$ mice (Oct), and global $1 \alpha \mathrm{OHase}^{-1-} \mathrm{KO}$ mice (Clobal). (C). Numbers refer to weeks after beginning adenine and data are expressed as the mean \pm SEM ( $n=6-8$ mice of each genotype). ${ }^{*} P \leq 0.01,{ }^{*} P \leq 0.05$ compared with mice of the same genotype maintained on a non-adenine-containing diet determined by ANOVA with Bonferroni adjustment.

was observed in the adenine-treated Oct-1 $\alpha(\mathrm{OH}) a s e^{-1-}$ mice that lacked osseous Cyp27b1, and expression remained high in the global-1 $\alpha(\mathrm{OH})$ ase $^{-/-}$mice that had global deletion of Cyp27b1. (Figure 4A).

Serum levels of BMP2 were significantly higher in Oct- $1 \alpha(\mathrm{OH}) \mathrm{ase}^{-/-}$mice compared with WT mice, indicating that locally produced $1,25(\mathrm{OH})_{2} \mathrm{D}$ also contributes to its circulating levels and were even higher in adenine-treated $\mathrm{OCt}-1(\mathrm{OH}) \mathrm{ase}^{-/-}$mice compared with adenine-treated WT mice (Figure 4B). Serum levels of BMP2 in global- $1 \alpha(\mathrm{OH})$ ase $^{-/-}$mice, with or without $\mathrm{CKD}$, were higher than the maximum measurable level, i.e., greater than $20,000 \mathrm{pg} / \mathrm{mL}$ (Figure $4 \mathrm{~B}$ ).

Extraskeletal calcification in situ. Because no extraskeletal calcification was seen in the absence of CKD (data not shown), we evaluated extraskeletal calcification of the mouse models in the presence of CKD. After 5 weeks on an adenine diet, both WT and Oct- $1 \alpha(\mathrm{OH})$ ase ${ }^{-/-}$mice developed ectopic calcification in aorta segments and hearts as imaged (Figure 5A) and quantified (Figure 5B) by $\mu \mathrm{CT}$. The same pattern of calcification was further confirmed by Von Kossa staining (Figure 5C) in which again the calcification was more severe in adenine-treated Oct-1 $\alpha(\mathrm{OH})$ ase ${ }^{-1-}$ mice compared with adenine-treated WT mice (Figure $5 \mathrm{C}$ ).

Sclerostin inhibits BMP2-induced osteoblastic transdifferentiation and calcification in vitro. Using vascular smooth muscle cells (A7r5) in vitro, we then examined the potential role of BMP2 and possible interaction of sclerostin and BMP2 in contributing to osteoblastic transdifferentiation and mineralization. The A7r5 cells were treated with BMP2 in the absence and presence of sclerostin, and the osteoblastic phenotype and calcification were determined by alkaline phosphatase (ALP) and Alizarin red staining, respectively. Evidence that BMP2 induced an osteoblast phenotype and mineralization was demonstrated by positive ALP and Alizarin red staining after adding BMP2 alone, but cotreatment with $100 \mathrm{ng} / \mathrm{mL}$ of human recombinant sclerostin significantly suppressed the BMP2 effect (Figure 6, A and B). ALP staining and mineralization were quantified for ALP activity (Figure $6 \mathrm{C}$ ) and by assessing calcium content normalized 
A

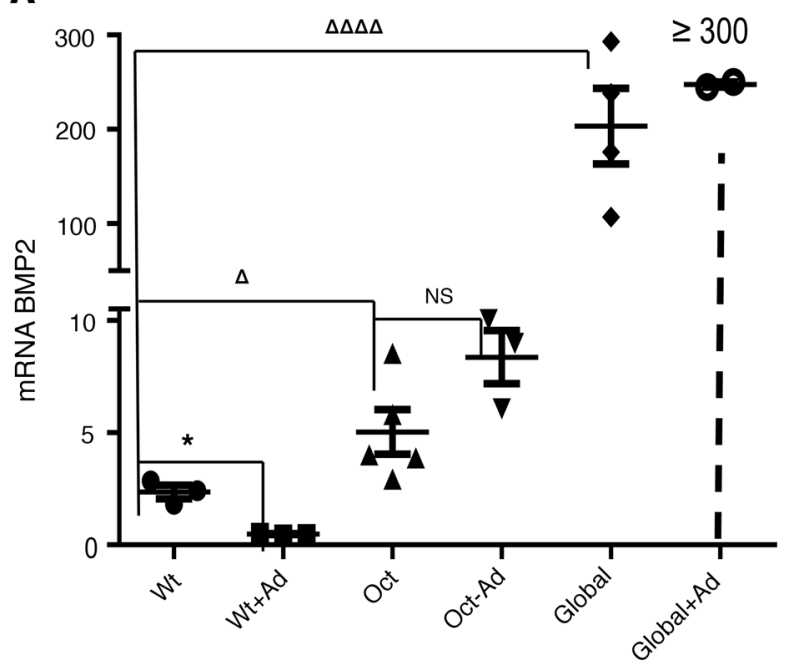

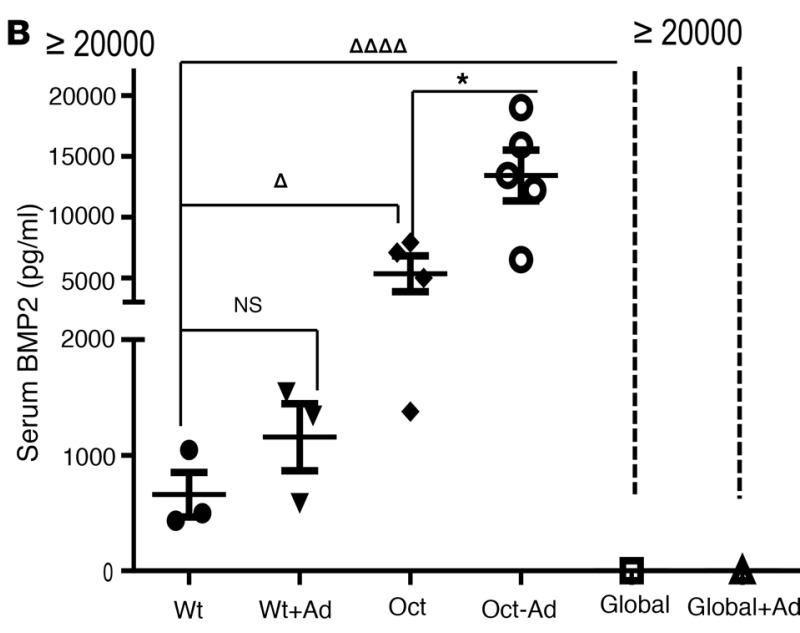

Figure 4. Bone BMP2 expression by RT-PCR and serum BMP2 levels. BMP2 mRNA expression in bone (A). Total RNA was extracted from bone marrowflushed femurs 13 weeks of age and mRNA levels of BMP2 were determined by RT-PCR. Data are expressed as mean \pm SEM, of 3-6 determinations normalized to Gapdh mRNA. ${ }^{\diamond 000} \mathrm{P} \leq 0.0001,{ }^{\diamond} \mathrm{P} \leq 0.05$ compared with WT mice not treated with adenine or to mice of the same genotype on a non-adeninecontaining diet ${ }^{*} P \leq 0.05$, determined by ANOVA with Bonferroni adjustment. Serum BMP2 levels at 13 weeks of age in mice of the indicated genotype (B). Data are expressed as mean \pm SEM, $\left(n=3-6\right.$ mice of each genotype) compared with mice of the same genotype on a non-adenine-containing diet ${ }^{*} P \leq$ 0.01 or compared to Wt mice ${ }^{\diamond \diamond \diamond \diamond} P \leq 0.0001,{ }^{\diamond} P \leq 0.05$ by ANOVA with Bonferroni adjustment

to protein levels (Figure 6D). BMP2 increased both ALP (Figure 6C) and calcium (Figure 6D), and these indices were reduced by coincubating cells with BMP2 plus sclerostin.

To further confirm an effect on osteoblastic transdifferentiation, expression of osteoblast-related genes was evaluated by real-time PCR (Figure 7). Our results demonstrated that BMP2 was able to significantly induce the expression of Alpl, Bglap, Rankl, and Runx2 in A7r5 cells and that cotreatment with $100 \mathrm{ng} / \mathrm{mL}$ of mouse recombinant sclerostin significantly suppressed the BMP2 effect (Figure 7).

\section{Discussion}

In this study, adenine-treated mice were evaluated over time to assess the early effects of osteocyte secretory activity on calcium deposition in soft tissues. Mice had not reached adulthood when assessed and it is possible that the deposition of calcium in growing bones in our mouse models acted as a reservoir for calcium (and other minerals); consequently, the growing bones could have mitigated extraskeletal mineralization that might otherwise have been even more pronounced than observed. In most mouse strains, peak bone mass is generally achieved at 4-6 months of age, as determined by dual-energy X-ray absorptiometry (47). However, use of adult mice might have introduced another potential confounder, i.e., loss of bone with aging (48) that generally occurs after 6 months and that might have accentuated extraskeletal bone mineralization. Irrespective of these considerations, vascular calcification has been recognized as an important consequence of CKD in both children (18) and adults, i.e., in the presence of both growing and resorbing skeletons, and the underlying pathophysiology at both life stages may be similar. However, further studies are needed to carefully examine these issues.

Renal tubular Cyp27b1 expression and consequent $1 \alpha(\mathrm{OH})$ ase activity is at least partly hormonally regulated, with positive effects of PTH and hypophosphatemia and negative regulation by FGF23, hypercalcemia, and generated $1,25(\mathrm{OH})_{2} \mathrm{D}$ (via "product inhibition"). In contrast, extrarenal Cyp27b1, as exemplified by macrophage Cyp27b1, is generally not regulated by PTH or calcium, but may be substrate dependent and can be regulated by cytokines (49). After induction of CKD in our studies, circulating levels of $1,25(\mathrm{OH})_{2} \mathrm{D}$, fell in WT mice (Figure 2) almost certainly the result of reduced renal synthesis secondary to adenine-induced renal damage. This point is reemphasized by the fact that in the absence of adenine administration (Figure 2), Oct- $1 \alpha(\mathrm{OH})$ ase $^{-/-}$mice, despite lacking osseous Cyp27b1, had circulating 1,25(OH) ${ }_{2} \mathrm{D}$ levels that were not significantly different than WT mice; circulating $1,25(\mathrm{OH})_{2} \mathrm{D}$ levels then fell in Oct- $1 \alpha(\mathrm{OH})$ $\mathrm{ase}^{-/-}$mice after adenine treatment, consistent with adenine-induced renal impairment. Furthermore, after adenine treatment, bone Cyp27b1 increased in osseous cells of WT mice with no rise in osseous Cyp24A1 $\left(24(\mathrm{OH})\right.$ ase) (Figure 2), consistent with increased production of intraosseous $1,25(\mathrm{OH})_{2} \mathrm{D}$, but this rise 
A
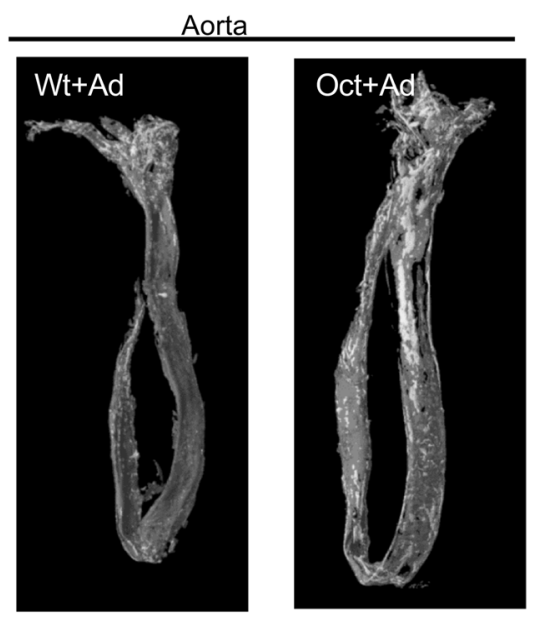

B

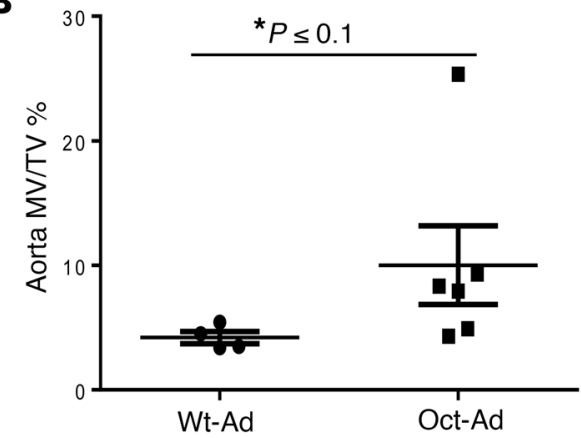

C
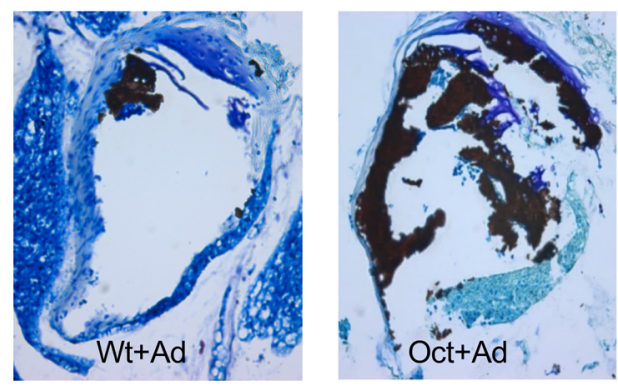

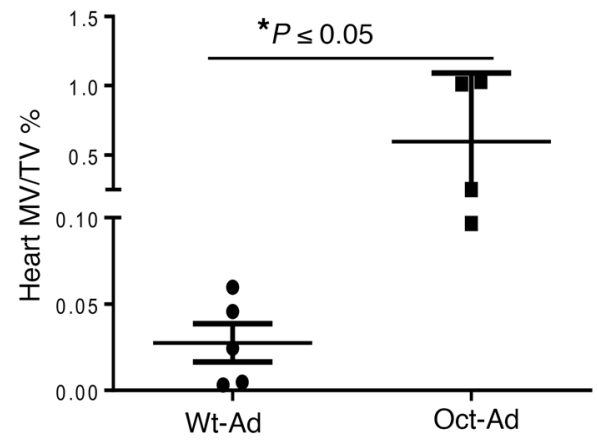

Figure 5. Extraskeletal calcification. Representative micro-CT scan-derived images from 3 independent experiments showing extraskeletal calcification (A). All groups of adenine-treated mice developed calcification in the aorta and heart. Calcification was more severe in adenine-treated Oct mice compared with adenine-treated WT mice. Quantitation of calcification of micro-CT images expressed as MV/TV (mineralized tissue volume/total tissue volume) (B). ${ }^{*} P \leq 0.1{ }^{* *} P \leq 0.05$ compared with adenine-treated WT mice determined by Student's $t$ test. Representative sections of Von Kossa staining of aorta segment and heart of mice of the indicated genotype (C). Calcified tissues stain black. Original magnification, $\times 200$.

was not reflected in circulating $1,25(\mathrm{OH})_{2} \mathrm{D}$ which fell after adenine treatment of the WT mice. These data emphasize that $1,25(\mathrm{OH})_{2} \mathrm{D}$ produced in osteocytic cells is not a source of circulating, hormonally active $1,25(\mathrm{OH})_{2} \mathrm{D}$ and likely acts locally as an intracrine/paracrine factor within the osseous cell.

Cytokines are increased early in kidney disease (50-52). Because proinflammatory cytokines are also able to activate the expression of Cyp27b1 (49), such cytokines/proinflammatory factors from adenine-induced kidney damage may well be the mediators of the early upregulation of Cyp27b1 in bone of WT mice in our CKD model. The increase of Cyp27b1 expression in bone was associated with increased expression of the osteocyte secretory product sclerostin as well as with higher circulating sclerostin levels, whereas specific deletion of Cyp27b1 in osteocytes significantly suppressed these changes. Our results thus align with a study in the $j c k$ mouse, a genetic model of polycystic kidney disease that exhibits progressive renal disease 

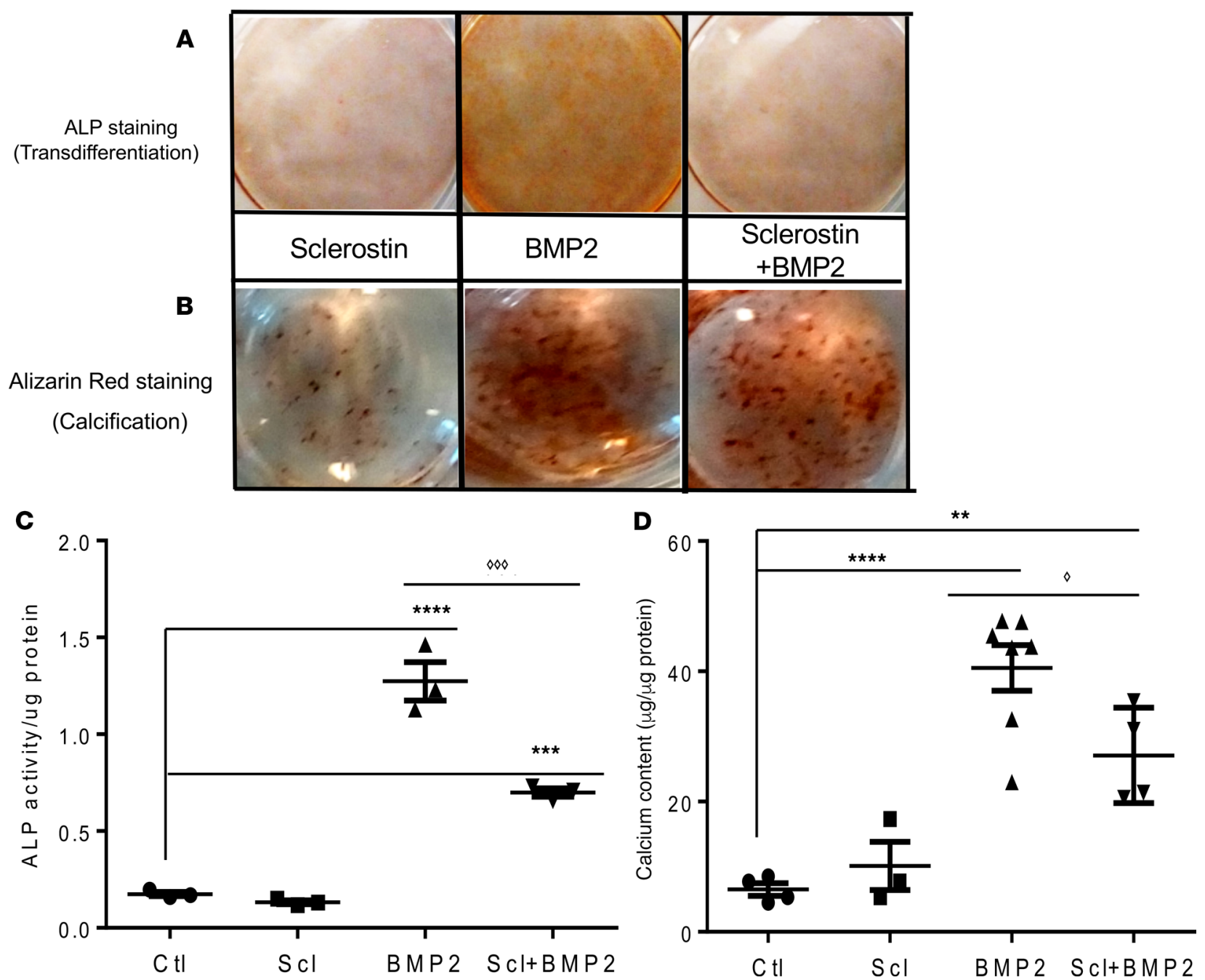

Figure 6. Sclerostin inhibits BMP2-induced transdifferentiation and calcification in vascular smooth muscle cells. Representative images of A7r5 vascular smooth muscle cells from 3 independent experiments. A7r5 cells were treated with BMP2 $(150 \mathrm{ng} / \mathrm{mL})$ in the presence and absence of sclerostin $(100 \mathrm{ng} / \mathrm{mL}$ ), and subjected to ALP (alkaline phosphatase) staining (A) and alizarin red staining (B). Red color denotes positive staining. Osteoblast transdifferentiation was quantified as ALP activity (C). Results are the mean \pm SEM of at least 3 independent experiments, ${ }^{* * * *} P<0.0001,{ }^{* * *} P$ $<0.0005$ compared with vehicle-treated cells, ${ }^{000} \mathrm{P}<0.0005$ compared to treatment of BMP2 alone, determined by ANOVA followed by Bonferroni adjustment. Osteoblast mineralization was quantified as calcium content normalized to the protein content, respectively. (D) Results are the mean \pm SEM of at least 3 independent experiments, ${ }^{* * *} P<0.0001,{ }^{* *} P<0.01$ compared with vehicle-treated cells, ${ }^{\triangleright} P \leq 0.05$ compared with treatment of BMP2 alone, determined by ANOVA followed by Bonferroni adjustment.

in which an increase of sclerostin was reported at an early stage of the disease (10), and also extend our previous findings that specific deletion of Cyp27b1 in bone significantly suppressed the rise in FGF23 in mice with adenine-induced CKD (4). Overall, our results suggest that the increases in FGF23 and sclerostin and the reduction in BMP2 we observed are at least in part the result of the effects of cytokines on stimulating osteocytic Cyp27b1 with resultant increased local production of $1,25(\mathrm{OH})_{2} \mathrm{D}$ in bone (Figure 8).

Deletion of Cyp27b1 from osteocytes increased osseous expression of Bmp2 both in the absence and presence of CKD, and serum BMP2 levels were elevated after Cyp27b1 deletion from osteocytes compared with WT mice, thus demonstrating the contribution of osteocytic BMP2 to circulating concentrations of BMP2. However, in WT mice with CKD, although Bmp2 skeletal expression was diminished when Cyp27b1 skeletal expression was increased, serum BMP2 levels were not lower, suggesting that extraskeletal sources of BMP2 may also contribute to circulating BMP2 in WT mice with CKD. This finding was supported by the elevated levels of serum BMP2 observed in the mice with global deletion of Cyp27b1 and suggests that negative regulation of BMP2 by $1,25(\mathrm{OH})_{2} \mathrm{D}$ also occurs in extraskeletal sites of BMP2 production. On a non-adenine-containing diet, the highest and lowest levels of Bmp2 mRNA were observed in mice with global deletion of $1 \alpha(\mathrm{OH})$ ase and in WT mice, 

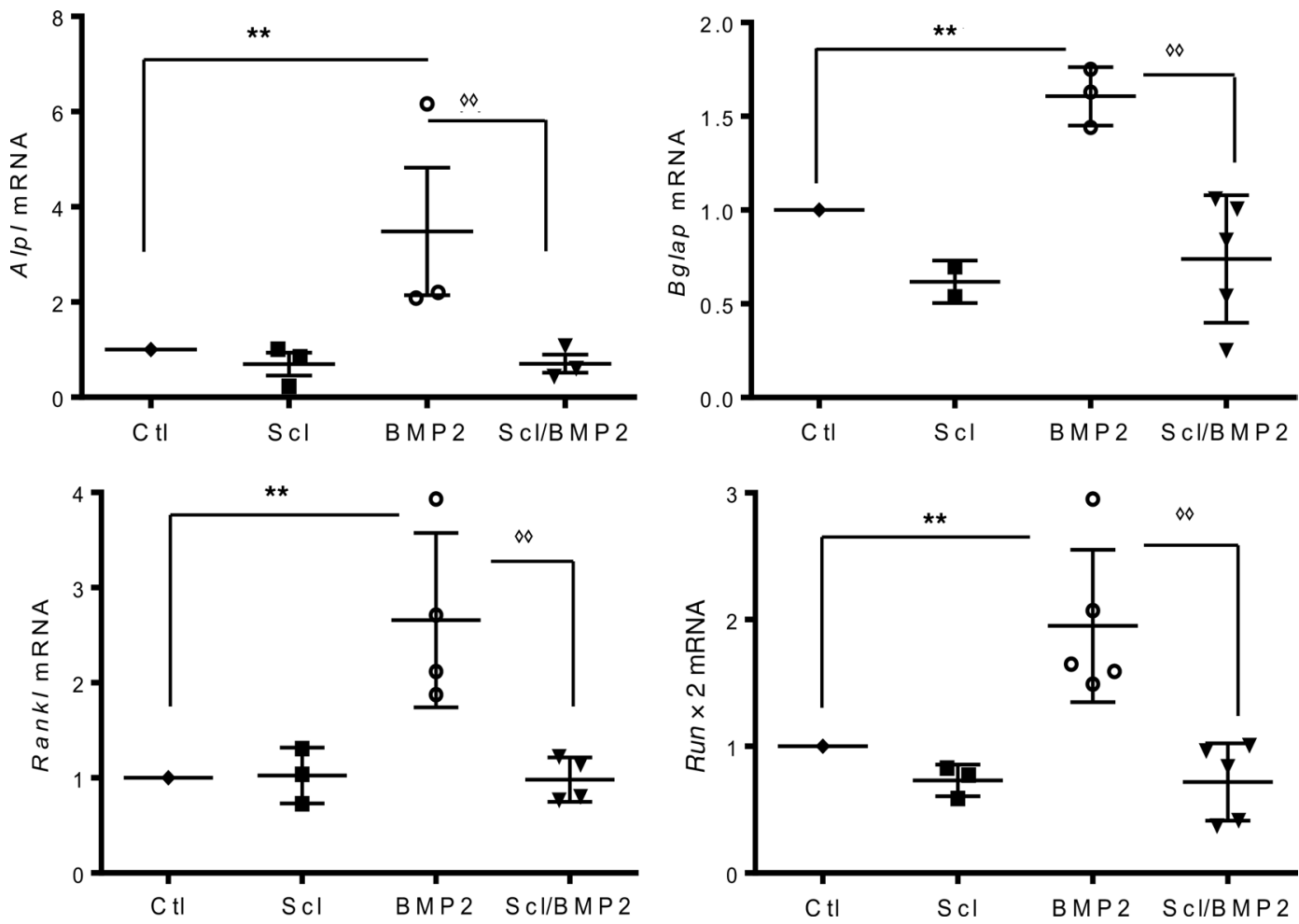

Figure 7. Gene expression of osteoblastic markers. Genes encoding the osteoblastic enzyme alkaline phosphatase (Alpl); the bone matrix protein osteocalcin, also called bone Gla-protein (Bglap); the osteoclast stimulator, receptor activator of nuclear factor $\kappa-\mathrm{B}$ ligand (Rankl); and the osteoblastic transcription factor, Runx2 (Runx2) were determined by real-time PCR, and expressed relative to Gapdh mRNA. Results are the mean \pm SEM of at least 3 independent experiments. Results were compared with vehicle-treated cells $\left({ }^{* *} P<0.01\right)$ or to cells treated only with BMP2 $\left({ }^{\diamond} P \leq 0.01\right)$ and determined by ANOVA followed by Bonferroni adjustment.

respectively, thus confirming an inhibiting effect of circulating $1.25(\mathrm{OH})_{2} \mathrm{D}$ levels on $B m p 2$ expression. Because circulating 1,25(OH) $)_{2} \mathrm{D}$ alone was not able to suppress the level of $B m p 2$ observed in Oct- $1 \alpha(\mathrm{OH}) \mathrm{ase}^{-/-}$mice compared with WT mice, there is evidence of an important contribution of local production of $1,25(\mathrm{OH})_{2} \mathrm{D}$, not only on Fgf23 and Sost induction but also on Bmp2 suppression. Overall, these findings suggest that bone represents a primary target in renal dysfunction and plays a dynamic role in the development and progression of $\mathrm{CKD}$ by increasing the expression of skeletal $1 \alpha$-hydroxylase and thus increasing local synthesis of $1,25(\mathrm{OH})_{2} \mathrm{D}$ that upregulates the production of Fgf23 and Sost and downregulates Bmp2.

The role of BMPs in mediating vascular calcification is supported by several in vivo studies. Thus, over-expression of BMP2 in smooth muscle accelerated vascular calcification in atherogenic mice (53), constitutive activation of BMP signaling induced ectopic calcification (54,55), and loss of matrix Gla protein (MGP), which may function as an endogenous BMP inhibitor, caused extensive calcification of elastic and muscular arteries (56). Taken together, these findings suggest that regulation of BMP activity is essential for maintaining normal blood vessel media.

Sclerostin, which inhibits the WNT signaling pathway (57), can, as a result of this action, inhibit bone formation promoted by BMP2 (57-59). Using vascular smooth muscle cells lines, we demonstrated that sclerostin was able to inhibit BMP2-induced osteoblastic differentiation in A7r5 cells and suppressed the expression of Runx2, Rankl, Bglap, and Alpl. Our results are supported by an in vitro study in calcified primary human aortic smooth muscle cells in which sclerostin was able to downregulate RUNX2 and recover $\alpha$-smooth muscle actin activity in calcification media (60) and by an in vivo study in which BMP-induced ectopic bone formation in calf muscle of mice was prevented by coexpression of sclerostin (57).

Therefore, our findings suggest that the inhibiting effects of sclerostin on the WNT pathway are not limited to bone but can also occur as an endocrine effect at extraskeletal sites. Thus, in Oct- $1 \alpha(\mathrm{OH})$ ase ${ }^{-1-}$ mice with $\mathrm{CKD}$, lower sclerostin and higher BMP2 levels accelerated soft-tissue transdifferentiation to osteoblastic cells and resultant calcification. The patchy soft-tissue mineralization that was observed in extraskeletal tissues in our 


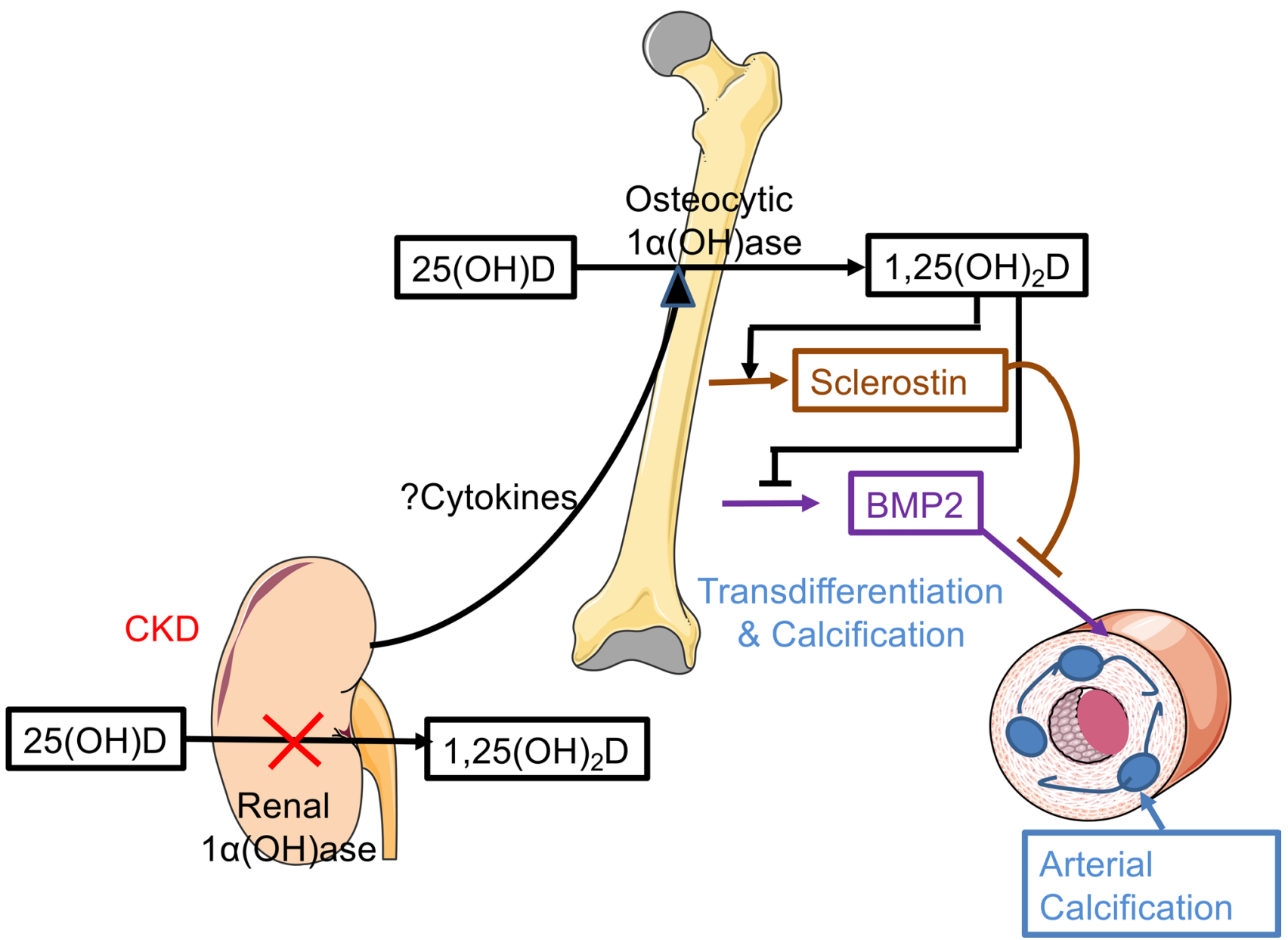

Figure 8. Model of effects of osseous sclerostin and BMP2 in arterial calcification in very early CKD. In the presence of $C K D$, the renal $1 \alpha(O H)$ ase is inactivated and less $250 \mathrm{HD}$ is converted to $1,25(\mathrm{OH})_{2} \mathrm{D}$. The damaged kidney stimulates the osteocytic $1 \alpha(\mathrm{OH})$ ase, likely via increased cytokine release, to augment local production of $1,25(\mathrm{OH})_{2} \mathrm{D}$. This can decrease BMP2 production in bone and stimulate sclerostin production. Sclerostin can inhibit BMP2-induced transdifferentiation of osseous cells in the arterial wall and reduce arterial calcification.

studies may have been the result of local tissue mechanisms that mitigate calcification. Thus, FGF21 has been reported to attenuate VSMC calcification in vitro via an FGF21/FGFR1/3/ $/$-klotho/P38MAPK/RUNX-2 signaling pathway (61), and myostatin, TGF- $\beta$, activin, IL-6, ciliary neurotrophic factor (CNTF), and monocyte chemotactic protein-1 (MCP-1) have all been reported to act as inhibitors of osteoblastic differentiation (19).

In conditions in which osteocytic Cyp27b1 was elevated, i.e., after adenine administration to WT mice (Figure 2), both serum FGF23 (Figure 1) and serum sclerostin (Figure 3) were elevated and extraskeletal calcification was low. In contrast, after deletion of Cyp27b1 from osteocytes or globally, serum FGF23 as well as sclerostin were reduced and calcification was increased. Consequently, reduced FGF23 also appeared to be associated with more severe extraskeletal calcification. Whether this was the result of increased phosphate retention as a result of the decreased renal action of reduced FGF23 or whether FGF23 exerts an as yet unknown inhibitory action on extraskeletal calcification remains to be determined in future studies; however, FGF23 has been reported to inhibit the Wnt pathway in osteoblasts (25).

Consequently, at an early stage of CKD, $1,25(\mathrm{OH})_{2} \mathrm{D}$-mediated increased production of osteocytic negative regulators of the WNT pathway, such as sclerostin, and FGF23 (34) may significantly mitigate ectopic calcification at extraskeletal sites (Figure 8). Some reduction in the glomerular filtration rate accompanies aging because of the physiologic reduction in the number of nephrons, and aging persons may also manifest osteoporosis, which may coexist with renal osteodystrophy (62). Although blocking antibodies to sclerostin increases bone mineral density in postmenopausal osteoporosis in women (63), our studies in mice may suggest that the use of sclerostin antibodies in uremic patients could accelerate vascular calcification and should be introduced with caution (64). 
In summary, in early $\mathrm{CKD}$, increase of the local osteocytic production of $1,25(\mathrm{OH})_{2} \mathrm{D}$, triggered by renal malfunction, may represent a "primary defensive response" to protect the organism from ectopic calcification by increasing sclerostin and by suppressing BMP2 production.

\section{Methods}

Materials. Recombinant Human/Mouse/Rat BMP2 (355-BEC-010) and Recombinant Human SOST/ Sclerostin Protein (T406-ST-025) were obtained from R\&D Systems. Sclerostin was reconstituted at 100 $\mu \mathrm{g} / \mathrm{mL}$ in sterile $4 \mathrm{mM} \mathrm{HCl}$ containing $0.2 \%$ BSA and BMP2 was reconstituted at $200 \mu \mathrm{g} / \mathrm{mL}$ in sterile PBS containing 0.1\% BSA. Fast Red TR/Naphthol AS-MX Alkaline Phosphatase Substrate Tablets Set (MilliporeSigma, F4523), Alkaline Phosphatase Yellow (pNPP) Liquid Substrate (MilliporeSigma, P7998), $\beta$-Glycerol 2-phosphate disodium salt hydrate (MilliporeSigma, G9422), and L-Ascorbic acid (MilliporeSigma, A4544) were obtained from MilliporeSigma and prepared according to the manufacturer's protocol.

A7r5 VSMCs, originally derived from embryonic rat aorta, were purchased from ATCC (ATCC-CRL-1444). They were grown in Minimum Essential Medium ( $\alpha \mathrm{MEM}$ ) supplemented with $10 \% \mathrm{FBS}, 150 \mathrm{units} / \mathrm{mL}$ penicillin, and $150 \mu \mathrm{g} / \mathrm{mL}$ streptomycin (Wisent). Cells were incubated at $37^{\circ} \mathrm{C}$ in $5 \% \mathrm{CO}_{2}$ and $95 \%$ air.

In vivo experiments. Mice were maintained in a virus and parasite-free barrier facility and exposed to a 12-hour/12-hour light/dark cycle. Eight-week-old C57BL/6N male mice were supplied by Charles River.

To generate mice lacking $1 \alpha(\mathrm{OH})$ ase in osteocytes (Oct-1 $\alpha(\mathrm{OH}) \mathrm{ase}^{-/-}$), the $9.6 \mathrm{~Kb}$ Dmp1-Cre mice (65) were obtained from the Jackson Laboratory and were mated with mice homozygous for a floxed Cyp27b1 allele, derived from mice generated in-house. Mice with global deletion of Cyp27b1 have been previously described (66) and were maintained on a high calcium diet containing $1.5 \%$ calcium gluconate (Thermo Fisher Scientific, A116490) in water throughout the study. For genotyping, genomic DNA was isolated from mouse tail and analyzed by PCR, for the DMP1-Cre using reverse primer (5'-TTGCCTTTCTCTCCACAGGT) and forward primer (F-primer) 5 '-CATGTCCATCAGGTTCTTGC and floxed-Cyp27b1 using reverse primer (R-primer) (5'-TGCAGACCAGTTTAAAAGTGGGCC) and forward primer (F-primer) (5'-TCCCAGACAGAGACATCCGTGTAGG) (67). Mice were maintained on standard chow or on an adenine diet to induce kidney injury. A CKD mouse model was developed by adapting an original rat model (68) with modifications for use in mice (4). Briefly 8-week-old male WT and Oct- $1 \alpha(\mathrm{OH})$ ase $^{-/-}$mice were kept on a regular diet (regular mouse chow) containing $0.25 \%$ adenine (Harlan Teklad), and global- $1 \alpha(\mathrm{OH})$ ase $^{-/-}$mice were kept on a diet containing $1.5 \%$ calcium gluconate (high calcium diet) and $0.25 \%$ adenine. Mice were sacrificed after up to 5 weeks, and serum, tissues, and bone were collected for analysis.

Serum biochemistry. Serum biochemistry was measured by the Diagnostic Laboratory of the Animal Resource Center of McGill University. Calcium (Ca) and phosphate $(\mathrm{P})$ were determined by autoanalyzer (Beckman Synchron 67, Beckman Instruments) and urea nitrogen (BUN) was measured by colorimetric assay. ELISAs were used, according to the manufacturer's protocol, to measure mouse intact PTH (ImmunoDiagnostic Systems), intact-FGF23 (Kaino), 25(OH)D (Immunodiagnostic Systems Ltd.), and 1,25(OH) D (Immunotopics).

Tissue harvest and histology. Tissues were collected and fixed overnight in Periodate-Lysine-Paraformaldehyde (PLP) fixative solution and placed in 70\% Ethanol. Fixed tissues were embedded in paraffin and sectioned.

For bone IHC, femur sections from 6-8 mice per experimental group were fixed in PLP and decalcified prior to the paraffin embedding. Primary anti-sclerostin antibody (AF1589; Goat IgG anti-mouse SOST Affinity Purified Ab, R\&D Systems) diluted 1:100 with 2\% rabbit serum in PBS was incubated with dewaxed paraffin sections overnight. After washing with high salt buffer, slides were incubated with secondary antibody, washed and processed using the Vectastain ABC-AP kit (Vector Laboratories), and mounted with Permount (Fisher Scientific). Images from 4 to 6 sections were processed blindly using image analysis software (Bioquant Image Analysis). IHC staining was quantified as the number of positively stained cells per surface area of bone tissue, using ImageJ (NIH) software (69).

To detect extraskeletal calcification, soft tissues were collected, fixed in PLP for $\mu$ CT analysis, embedded in paraffin and sectioned. Sections were stained for mineral using the Von Kossa staining procedure.

$R N A$ extraction and quantitative real-time PCR. After flushing out the bone marrow, total RNA was extracted from long bone using the TRIzol reagent (Invitrogen) according to the manufacturer's protocol, then reverse transcribed into cDNA using SuperScript II (Invitrogen), and end analyzed by quantitative real-time (RT) PCR using the following primer: Cyp27b1, forward 5'-CAAACCCTGGAAAGCCTATCG and reverse 5'-CGCTGCCACTCCTGTCCTT; Cyp24a1, forward 5'-ACCGTGGACAGAACGCAATGG-3' and reverse 5'-AAATCCAGAGCGTGCTGCCTG-3'; Bmp2, forward 5'-GGTCACAGATAAGGCATTGC and reverse 
5'-GCTTCCGCTGTTTGTGTTTG; Alpl, forward 5'-ACACCTTGACTGTGGTTACTGCTGA and reverse 5'-CCTTGTAGCCAGGCCCGTTA; Rankl, forward 5'-GATTTTTCAAGCTCCGAGCTG and reverse 5'-CCTGAACTTTGAAAGCCCCAA; Runx2, forward, 5'-AATTGCAGGCTTCGTGGTTG and reverse 5'-TCCCCTGAATGGCTGTATGGT; Bglap, forward 5'-TTCTGCTCACTCTGCTGACCCT and reverse -5'-CCTGCTTGGACATGAAGGCTT; Gapdh, forward 5'-GCATCTCCCTCACAATTTCCA and reverse 5'-GTGCAGCGAACTTTATTGATGG. Relative expression values were evaluated with the $2-\Delta \Delta C$ method and values were normalized to Gapdh signals. cDNAs from 3 independent experiments were analyzed.

Microcomputed tomography. Fixed tissues were analyzed by microcomputed tomography $(\mu \mathrm{CT})$ with a SkyScan 1072 scanner and associated analysis software (SkyScan) as described (70). For quantitation of calcification, 3-dimensional renderings of the samples were reconstructed using 2-dimensional data from scanned slices with the 3D Creator software supplied with the instrument. The region of interest was drawn, and 3-dimensional analysis was performed to calculate mineralized tissue volume (MV)/total tissue volume (TV). The resolution of the microcomputed tomography images was $18.2 \mu \mathrm{m}$.

In vitro experiments. The A7r5 cells were maintained in minimal essential medium ( $\alpha$-MEM) supplemented with $10 \%$ FBS, 150 units $/ \mathrm{mL}$ penicillin, and $150 \mu \mathrm{g} / \mathrm{mL}$ streptomycin. Transdifferentiation of vascular smooth muscle cells was studied in regular growth medium. A7r5 cells were cultured in 6-well plates in $\alpha$-MEM; after reaching full confluence, BMP2 $(150 \mathrm{ng} / \mathrm{mL})$ was added for 24 hours after pretreatment with sclerostin (100 ng/mL) for 24 hours. The reaction was stopped by washing with PBS. RNA was extracted for gene expression analysis. Histochemical staining for ALP was carried out using naphthol AS-MX phosphate (MilliporeSigma, F4523) and ALP activity in the cells was determined using Alkaline Phosphatase Yellow (pNPP) Liquid Substrate (MilliporeSigma, P7998) according to the manufacturer's protocol.

Mineralization was assessed by Alizarin red staining, and the calcium content was determined using a calcium colorimetric assay kit (BioAssay Systems, DICA-500). Following decalcification using $0.6 \mathrm{~N} \mathrm{HCl}$ and solubilization with $0.1 \mathrm{~N} \mathrm{NaOH} / 0.1 \% \mathrm{SDS}$, the protein content was measured using Bradford's method (Bio-Rad Protein Assay, 500-0006).

Statistics. Statistical comparisons, using Graph-Pad Prism analysis software were made using 2-tailed Student's $t$ test or ANOVA, followed by a Bonferroni multiple comparison test. $P \leq 0.05$ was considered significant.

Study approval. All animal protocols were reviewed by the McGill University Animal Care and Use Committee, and experiments were carried out in compliance with and approval of this institutional review board.

\section{Author contributions}

LNY, KIT, and DG designed the study. LNY and KIT performed research. LNY, KIT, and DG analyzed data. RSTA contributed reagents/analytic tools; and all authors were involved in drafting and revising the manuscript and approved the final version of manuscript.

\section{Acknowledgments}

This study was supported by a grant (number PJT-152963) from the Canadian Institutes for Health Research to DG.

Address correspondence to: David Goltzman, McGill University Health Centre, Glen Site, 1001 Decarie Boulevard, Room EM1.3220, Montreal, Quebec, Canada, H4A 3J1. Phone: 514.843.1632; Email: david. goltzman@mcgill.ca.

KIT's present address is: Department of Internal Medicine 1, Faculty of Medicine, Shimane University, Shimane, Japan.

1. Budoff MJ, et al. Relationship of estimated GFR and coronary artery calcification in the CRIC (Chronic Renal Insufficiency Cohort) Study. Am J Kidney Dis. 2011;58(4):519-526.

2. Gutierrez $\mathrm{O}$, et al. Fibroblast growth factor-23 mitigates hyperphosphatemia but accentuates calcitriol deficiency in chronic kidney disease. J Am Soc Nephrol. 2005;16(7):2205-2215.

3. Isakova $\mathrm{T}$, et al. Fibroblast growth factor 23 is elevated before parathyroid hormone and phosphate in chronic kidney disease. Kidney Int. 2011;79(12):1370-1378.

4. Nguyen-Yamamoto L, Karaplis AC, St-Arnaud R, Goltzman D. Fibroblast growth factor 23 regulation by systemic and local osteoblast-synthesized 1,25-dihydroxyvitamin D. J Am Soc Nephrol. 2017;28(2):586-597.

5. Rotondi S, et al. Soluble $\alpha$-Klotho serum levels in chronic kidney disease. Int J Endocrinol. 2015;2015:872193. 
6. Dallas SL, Prideaux M, Bonewald LF. The osteocyte: an endocrine cell...and more. Endocr Rev. 2013;34(5):658-690.

7. Matsubara H, Hogan DE, Morgan EF, Mortlock DP, Einhorn TA, Gerstenfeld LC. Vascular tissues are a primary source of BMP2 expression during bone formation induced by distraction osteogenesis. Bone. 2012;51(1):168-180.

8. McBride SH, et al. Long bone structure and strength depend on BMP2 from osteoblasts and osteocytes, but not vascular endothelial cells. PLoS One. 2014;9(5):e96862.

9. Nomura S, Takano-Yamamoto T. Molecular events caused by mechanical stress in bone. Matrix Biol. 2000;19(2):91-96.

10. Sabbagh Y, et al. Repression of osteocyte Wnt/ $\beta$-catenin signaling is an early event in the progression of renal osteodystrophy. $J$ Bone Miner Res. 2012;27(8):1757-1772.

11. Shao JS, Cheng SL, Pingsterhaus JM, Charlton-Kachigian N, Loewy AP, Towler DA. Msx2 promotes cardiovascular calcification by activating paracrine Wnt signals. J Clin Invest. 2005;115(5):1210-1220.

12. Pelletier S, Dubourg L, Carlier MC, Hadj-Aissa A, Fouque D. The relation between renal function and serum sclerostin in adult patients with CKD. Clin J Am Soc Nephrol. 2013;8(5):819-823.

13. Urist MR. Bone: formation by autoinduction. Science. 1965;150(3698):893-899.

14. Nomura S, Takano-Yamamoto T. Molecular events caused by mechanical stress in bone. Matrix Biol. 2000;19(2):91-96.

15. Westendorf JJ, Kahler RA, Schroeder TM. Wnt signaling in osteoblasts and bone diseases. Gene. 2004;341:19-39.

16. Johnson ML, Harnish K, Nusse R, Van Hul W. LRP5 and Wnt signaling: a union made for bone. J Bone Miner Res. 2004;19(11):1749-1757.

17. van der Horst G, van der Werf SM, Farih-Sips H, van Bezooijen RL, Löwik CW, Karperien M. Downregulation of Wnt signaling by increased expression of Dickkopf-1 and -2 is a prerequisite for late-stage osteoblast differentiation of KS483 cells. $J$ Bone Miner Res. 2005;20(10):1867-1877.

18. Querfeld U, Schaefer F. Cardiovascular risk factors in children on dialysis: an update [published online ahead of print October 31, 2018]. Pediatr Nephrol. https://doi.org/10.1007/s00467.018.4125-x.

19. Kaji H. Effects of myokines on bone. Bonekey Rep. 2016;5:826.

20. Molinuevo MS, Fernández JM, Cortizo AM, McCarthy AD, Schurman L, Sedlinsky C. Advanced glycation end products and strontium ranelate promote osteogenic differentiation of vascular smooth muscle cells in vitro: Preventive role of vitamin $\mathrm{D}$ Mol Cell Endocrinol. 2017;450:94-104.

21. Byon $\mathrm{CH}$, et al. Oxidative stress induces vascular calcification through modulation of the osteogenic transcription factor Runx2 by AKT signaling. J Biol Chem. 2008;283(22):15319-15327.

22. Sutra T, Morena M, Bargnoux AS, Caporiccio B, Canaud B, Cristol JP. Superoxide production: a procalcifying cell signalling event in osteoblastic differentiation of vascular smooth muscle cells exposed to calcification media. Free Radic Res. 2008;42(9):789-797.

23. Otto F, et al. Cbfa1, a candidate gene for cleidocranial dysplasia syndrome, is essential for osteoblast differentiation and bone development. Cell. 1997;89(5):765-771.

24. Schroeder TM, Jensen ED, Westendorf JJ. Runx2: a master organizer of gene transcription in developing and maturing osteoblasts. Birth Defects Res C Embryo Today. 2005;75(3):213-225.

25. Hu H, Hilton MJ, Tu X, Yu K, Ornitz DM, Long F. Sequential roles of Hedgehog and Wnt signaling in osteoblast development. Development. 2005;132(1):49-60.

26. Goltzman D. LRP5, serotonin, and bone: complexity, contradictions, and conundrums. J Bone Miner Res. 2011;26(9):1997-2001

27. Xu Q, Cui Y, Luan J, Zhou X, Li H, Han J. Exosomes from C2C12 myoblasts enhance osteogenic differentiation of MC3T3-E1 pre-osteoblasts by delivering miR-27a-3p. Biochem Biophys Res Commun. 2018;498(1):32-37.

28. Gaur T, et al. Canonical WNT signaling promotes osteogenesis by directly stimulating Runx2 gene expression. J Biol Chem. 2005;280(39):33132-33140.

29. Al-Aly Z, et al. Aortic Msx2-Wnt calcification cascade is regulated by TNF- $\alpha$-dependent signals in diabetic Ldlr ${ }^{-/-}$mice. Arterioscler Thromb Vasc Biol. 2007;27(12):2589-2596.

30. van Bezooijen RL, et al. Wnt but not BMP signaling is involved in the inhibitory action of sclerostin on BMP-stimulated bone formation. J Bone Miner Res. 2007;22(1):19-28

31. Li X, et al. Sclerostin binds to LRP5/6 and antagonizes canonical Wnt signaling. J Biol Chem. 2005;280(20):19883-19887.

32. Semënov M, Tamai K, He X. SOST is a ligand for LRP5/LRP6 and a Wnt signaling inhibitor. J Biol Chem. 2005;280(29):26770-26775.

33. McArthur KM, Kay AM, Mosier JA, Grant JN, Stewart JA, Simpson CL. Manipulating the plasticity of smooth muscle cells to regulate vascular calcification. AIMS Cell and Tissue Engineering. 2017;1(3):165-179.

34. Carrillo-López N, et al. Direct inhibition of osteoblastic Wnt pathway by fibroblast growth factor 23 contributes to bone loss in chronic kidney disease. Kidney Int. 2016;90(1):77-89.

35. Schmidt N, Brandsch C, Kühne H, Thiele A, Hirche F, Stangl GI. Vitamin D receptor deficiency and low vitamin D diet stimulate aortic calcification and osteogenic key factor expression in mice. PLoS One. 2012;7(4):e35316.

36. Dobnig $\mathrm{H}$, et al. Independent association of low serum 25-hydroxyvitamin d and 1,25-dihydroxyvitamin d levels with all-cause and cardiovascular mortality. Arch Intern Med. 2008;168(12):1340-1349.

37. Giovannucci E, Liu Y, Hollis BW, Rimm EB. 25-hydroxyvitamin D and risk of myocardial infarction in men: a prospective study. Arch Intern Med. 2008;168(11):1174-1180.

38. Wang TJ, et al. Vitamin D deficiency and risk of cardiovascular disease. Circulation. 2008;117(4):503-511.

39. Artaza JN, Mehrotra R, Norris KC. Vitamin D and the cardiovascular system. Clin J Am Soc Nephrol. 2009;4(9):1515-1522.

40. Kilkkinen A, et al. Vitamin D status and the risk of cardiovascular disease death. Am J Epidemiol. 2009;170(8):1032-1039.

41. Mathew S, Lund RJ, Chaudhary LR, Geurs T, Hruska KA. Vitamin D receptor activators can protect against vascular calcification. J Am Soc Nephrol. 2008;19(8):1509-1519.

42. Torremadé $\mathrm{N}$, et al. Vascular calcification induced by chronic kidney disease is mediated by an increase of $1 \alpha$-hydroxylase expression in vascular smooth muscle cells. J Bone Miner Res. 2016;31(10):1865-1876.

43. Wijenayaka AR, et al. Early response of the human SOST gene to stimulation by $1 \alpha, 25$-dihydroxyvitamin D. J Steroid Biochem Mol Biol. 2016;164:369-373. 
44. Sebastian A, Loots GG. Transcriptional control of Sost in bone. Bone. 2017;96:76-84.

45. Wijenayaka AR, et al. 1 $\alpha, 25$-dihydroxyvitamin D3 stimulates human SOST gene expression and sclerostin secretion. Mol Cell Endocrinol. 2015;413:157-167.

46. Fu B, et al. Epigenetic regulation of BMP2 by 1,25-dihydroxyvitamin D3 through DNA methylation and histone modification PLoS One. 2013;8(4):e61423.

47. Jilka RL. The relevance of mouse models for investigating age-related bone loss in humans. J Gerontol A Biol Sci Med Sci. 2013;68(10):1209-1217.

48. Ackert-Bicknell C, Beamer WG, Rosen CJ, Sundberg JP. 2016. Ackert1: Aging study: Bone mineral density and body composition of 32 inbred strains of mice (2008). Mouse Phenome Database (RRID:SCR_003212). The Jackson Laboratory. https:// phenome.jax.org/projects/Ackert1. Accessed June 20, 2019.

49. Bikle DD. Vitamin D and immune function: understanding common pathways. Curr Osteoporos Rep. 2009;7(2):58-63.

50. Vianna HR, Soares CM, Tavares MS, Teixeira MM, Silva AC. [Inflammation in chronic kidney disease: the role of cytokines]. $J$ Bras Nefrol. 2011;33(3):351-364.

51. Perlman AS, et al. Serum inflammatory and immune mediators are elevated in early stage diabetic nephropathy. Ann Clin Lab Sci. 2015;45(3):256-263.

52. Durlacher-Betzer K, Hassan A, Levi R, Axelrod J, Silver J, Naveh-Many T. Interleukin-6 contributes to the increase in fibroblast growth factor 23 expression in acute and chronic kidney disease. Kidney Int. 2018;94(2):315-325.

53. Nakagawa Y, et al. Paracrine osteogenic signals via bone morphogenetic protein-2 accelerate the atherosclerotic intimal calcification in vivo. Arterioscler Thromb Vasc Biol. 2010;30(10):1908-1915.

54. Shore EM, et al. A recurrent mutation in the BMP type I receptor ACVR1 causes inherited and sporadic fibrodysplasia ossificans progressiva. Nat Genet. 2006;38(5):525-527.

55. Yu PB, et al. BMP type I receptor inhibition reduces heterotopic [corrected] ossification. Nat Med. 2008;14(12):1363-1369.

56. Luo G, et al. Spontaneous calcification of arteries and cartilage in mice lacking matrix GLA protein. Nature. 1997;386(6620):78-81.

57. van Bezooijen RL, et al. Wnt but not BMP signaling is involved in the inhibitory action of sclerostin on BMP-stimulated bone formation. J Bone Miner Res. 2007;22(1):19-28.

58. Kamiya N, et al. Wnt inhibitors Dkk1 and Sost are downstream targets of BMP signaling through the type IA receptor (BMPRIA) in osteoblasts. J Bone Miner Res. 2010;25(2):200-210.

59. Winkler DG, et al. Sclerostin inhibition of Wnt-3a-induced C3H10T1/2 cell differentiation is indirect and mediated by bone morphogenetic proteins. J Biol Chem. 2005;280(4):2498-2502.

60. McArthur KM, Kay AM, Mosier JA, Grant JN, Stewart JA, Simpson CL. Manipulating the plasticity of smooth muscle cells to regulate vascular calcification. AIMS Cell and Tissue Engineering. 2017;1(3):165-179.

61. Cao F, et al. Fibroblast growth factor 21 attenuates calcification of vascular smooth muscle cells in vitro. J Pharm Pharmacol. 2017;69(12):1802-1816.

62. Tartaglione L, Pasquali M, Rotondi S, Muci ML, Covic A, Mazzaferro S. Positioning novel biologicals in CKD-mineral and bone disorders. J Nephrol. 2017;30(5):689-699.

63. McClung MR, et al. Romosozumab in postmenopausal women with low bone mineral density. NEngl J Med. 2014;370(5):412-420.

64. Brandenburg VM, Verhulst A, Babler A, D'Haese PC, Evenepoel P, Kaesler N. Sclerostin in chronic kidney disease-mineral bone disorder think first before you block it! Nephrol Dial Transplant. 2019;34(3):408-414.

65. Lu Y, Xie Y, Zhang S, Dusevich V, Bonewald LF, Feng JQ. DMP1-targeted Cre expression in odontoblasts and osteocytes. $J$ Dent Res. 2007;86(4):320-325.

66. Panda DK, et al. Targeted ablation of the 25-hydroxyvitamin D 1alpha -hydroxylase enzyme: evidence for skeletal, reproductive, and immune dysfunction. Proc Natl Acad Sci U S A. 2001;98(13):7498-7503.

67. Naja RP, Dardenne O, Arabian A, St Arnaud R. Chondrocyte-specific modulation of Cyp27b1 expression supports a role for local synthesis of 1,25-dihydroxyvitamin D3 in growth plate development. Endocrinology. 2009;150(9):4024-4032.

68. Yokozawa T, Zheng PD, Oura H. Experimental renal failure rats induced by adenine - evaluation of free amino acid, ammonia nitrogen and guanidino compound levels. Agric Biol Chem. 1983;47:2341-2348.

69. Schneider CA, Rasband WS, Eliceiri KW. NIH Image to ImageJ: 25 years of image analysis. Nat Methods. 2012;9(7):671-675

70. Samadfam R, Xia Q, Goltzman D. Pretreatment with anticatabolic agents blunts but does not eliminate the skeletal anabolic response to parathyroid hormone in oophorectomized mice. Endocrinology. 2007;148(6):2778-2787. 